WHAT CHANGED WHEN EVERYTHING CHANGED 
This page intentionally left blank 
JOSEPH MARGULIES

\title{
What Changed
} When Everything Changed

9/11 AND THE MAKING OF NATIONAL IDENTITY

\author{
Yale
}

UNIVERSITY PRESS

NEW HAVEN \& LONDON 
Copyright (C) 2013 by Joseph Margulies.

All rights reserved.

This book may not be reproduced, in whole or in part, including illustrations, in any form (beyond that copying permitted by Sections I07 and Io8 of the U.S. Copyright Law and except by reviewers for the public press), without written permission from the publishers.

Yale University Press books may be purchased in quantity for educational, business, or promotional use. For information, please e-mail sales.press@yale.edu (U.S. office) or sales@yaleup.co.uk (U.K. office).

Set in Scala and Scala Sans types by Integrated Publishing Solutions. Printed in the United States of America.

Library of Congress Cataloging-in-Publication Data

Margulies, Joseph.

What changed when everything changed : 9/II and the making of national identity / Joseph Margulies.

pages $\mathrm{cm}$

Includes bibliographical references and index.

ISBN 978-0-300-I7655-I (cloth : alk. paper) I. National characteristics, American. 2. Nationalism-United States. 3. September II Terrorist Attacks, 200I-Influence. 4. Terrorism-United States-PreventionSocial aspects. 5. United States-History-2Ist century. I. Title.

$$
\begin{gathered}
\text { EI69.I.M264 } 2013 \\
973.93-\mathrm{dc} 23 \\
2012049865
\end{gathered}
$$

A catalogue record for this book is available from the British Library.

This paper meets the requirements of ANSI/NISO Z39.48-I992

(Permanence of Paper).

$$
\text { IO } 98765432 \text { I }
$$


To Sid Tarrow and CVW 
This page intentionally left blank 